\title{
PENERAPAN SISTEM HEMAT ENERGI PADA GEDUNG MENARA PHINISI, KOTA MAKASSAR
}

\author{
Ratriana Said, Syafril Nanar, Burhanuddin \\ Jurusan Teknik Arsitektur \\ Fakultas Sains dan Teknologi UIN Alauddin Makassar \\ Jl. Sultan Alauddin No. 63, Kabupaten Gowa, Sulawesi Selatan. 92113 \\ E-mail: ratriana@gmail.com
}

\begin{abstract}
Global warming is an issue that is currently often discussed by many people. One of the causes of global warming can be seen from the use of quite a lot of electrical energy in a building or building. This pressures the architects to play a role in designing a building that can save energy by paying attention and utilizing the surrounding climate conditions. Energy saving architecture is a concept that is offered to reduce excessive energy use. The object under study is the phinisi tower by collecting descriptive qualitative data. The purpose of this research is to find out the concept of applying energy saving phinisi towers that we can see with designs that make better use of climate in the context of natural ventilation.
\end{abstract}

Keywords: energy saving, global warming, phinisi tower

\section{PENDAHULUAN}

$\mathrm{P}$

emanasan global merupakan isu yang saat ini sering diperbincangkan banyak orang. Ada banyak dampak yang ditimbulkan oleh pemanasan global dimana grafik peningkatan suhunya naik secara signifikan. Hal ini tidak dapat dihentikan, sebab model perkembangan dunia yang semakin canggih sehingga kebutuhan akan energi yang banyak memicu terjadinya krisis sumber energi.

Salah satu sebab dari pemanasan global ini dapat kita lihat dari penggunaan energi listrik yang cukup banyak pada sebuah bangunan atau gedung. Hal ini menekan para arsitek untuk berperan dalam merancang sebuah bangunan yang dapat menghemat energi dengan memperhatikan dan memanfaatkan kondisi iklim sekitar. Mengenai hal tersebut, solusi yang ditawarkan untuk meminimalisir keadaan ini khususnya pada bangunan tinggi adalah konsep ekologi arsitektur. Dimana konsep ini berperan untuk mengefisienkan penggunaan energi yang berlebihan serta menekan konsep desain yang tetapi juga dampak lingkungan yang berkelanjutan.

Konsep ekologi arsitektur itu memiliki beberapa cabang. Salah satu diantaranya adalah arsitektur hemat energi. Hal ini merupakan sebuah konsep yang ditawarkan untuk menekan penggunaan energi berlebihan secara efisien.

Menara phinisi merupakan salah satu bangunan yang dirancang dengan meminimalkan penggunaan energi berlebihan melalui pemanfaatan kondisi iklim sekitar. Selain itu, penggunan elemen- elemen yang tepat mendukung konsep perancangan ini dalam meminimalisirkan penggunan energi tersebut. 


\section{METODE PENELITIAN}

Penelitian ini dilakukan dengan metode pengumpulan data secara kualitatif deskriptif. Objek pada penelitian ini adalah gedung Menara Phinisi Universitas Negeri Makassar yang terletak di Jl. A. P. Pettarani Kec. Rappocini Kota Makassar.

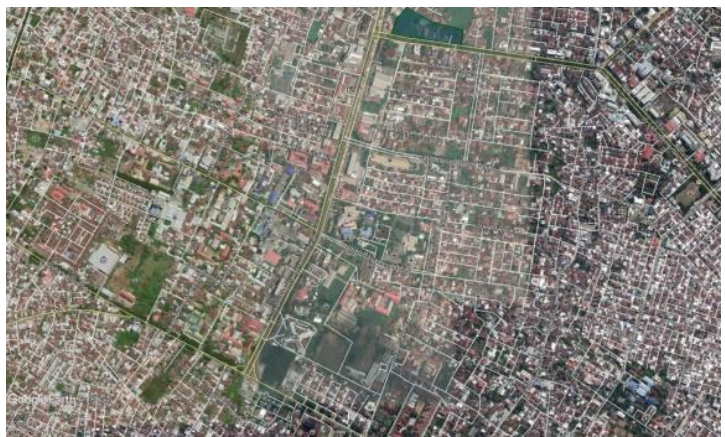

Gambar 1. Peta lokasi (Sumber: Google Earth Pro, 2019)

Waktu penelitian dilakukan secara fleksibel karena pengumpulan data yang dilakukan secara kualitatif berdasarkan penelitian yang telah ada dan juga berupa dokumentasi dalam bentuk foto kemudian mengaitkannya dengan prinsip dan teori arsitektur hemat energi.

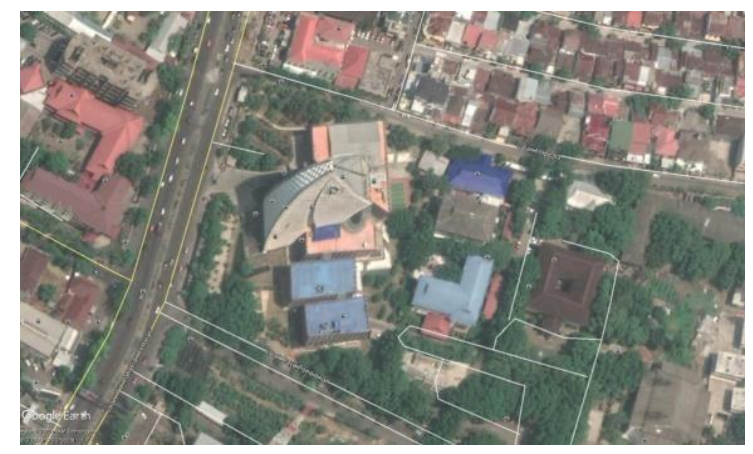

Gambar 2. Site plan (Sumber: Google Earth Pro, 2019)

\section{HASIL DAN PEMBAHASAN}

\section{A. Prinsip Arsitektur Hemat Energi}

Berdasarkan metode penelitian yang digunakan yaitu secara kualitatif dengan mengaitkan data dengan teori prinsip arsitektur hemat energi. Pada dasarnya, arsitektur hemat energi merupakan klasifikasi arsitektur berkelanjutan. Dimana konsep arsitektur berkelanjutan dirancang sedemikian rupa dalam memenuhi kebutuhan saat ini tanpa merusak dan memberikan dampak negatif terhadap generasi selanjutnya. Sehingga upaya yang dilakukan adalah meminimalisir penggunaan energi pada sebuah bangunan atau gedung. Ada beberapa konsep dalam penerapan arsitektur berkelanjutan yaitu:

Biaya operasi dan pemeliharaan gedung yang rendah. Sebagai konsep yang sangat menekankan sistem keberlanjutannya, maka biaya operasi dan pemeliharaan pada sebuah bangunan itu harus diperhatikan bagaimana agar konsep tersebut dapat terpenuhi saat ini tanpa merusak kedepannya untuk para generasi selanjutnya. Salah satu alur pikir yang digunakan adalah bagaimana memanfaatkan kondisi iklim dalam penghematan operasi pada bangunan tersebut. 


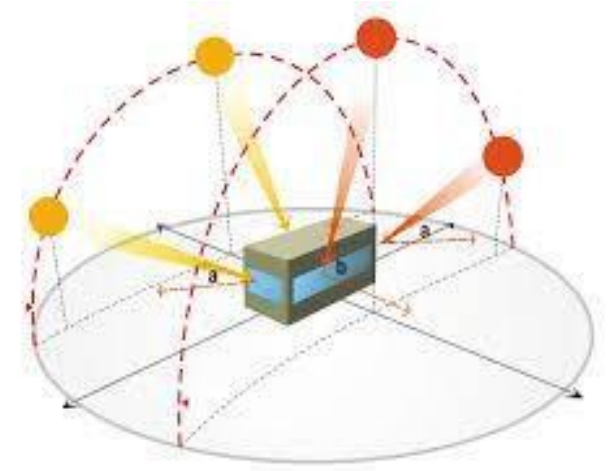

Gambar 3. Ilustrasi pemanfaatan iklim matahari dalam efisiensi penggunaan energi (Sumber: greenbuilding.jakarta.go.id, 2012)

Melindungi kelestarian alam dengan lingkungannya. Penekanan pada pengertian yang merujuk pada keberlangsungan generasi selanjutnya, maka poin untuk menjaga dan melindungi kelesatarian alam dengan lingkungan sekitarnya merupakan prinsip dalam mendukung konsep ini. Karena dengan terusungnya pemikiran pada penjagaan kelestarian dapat memberikan dampak positif bagi keberlanjutan masa depan generasi.

Memperhatikan kenyamanan, keamanan, serta keindahannya. Prinsip arsitektur berkelanjutan adalah salah satu prinsip yang memperhatikan berbagai aspek masalah, sehingga upaya dalam memberikan perancangan yang baik itu juga harus ditanamkan nilai keamanan, kenyamanan, dan keindahannya.

Mempertahankan nilai-nilai dan budaya setempat. Dalam hal memenuhi kebutuhan saat ini, konsep arsitektur berkelanjutan juga harus memperhatikan bagaimana kehidupan dan budaya serta nilai-nilai yang berlaku pada masyarakat setempat. Sehingga dengan mempertahankan nilai dan budaya tersebut dapat memberikan kesinambungan dan pelajaran bagi generasi selanjutnya tanpa melupakan dan mmenghilangkan sejarah kehidupan dimasa lalu.

Beberapa prinsip di atas merupakan tolak ukur dalam mengusung konsep arsitektur hemat energi yaitu khususnya suistinable development. Tolak ukur tersebut di antaranya: keberlanjutan ekonomi (ecomonic sustainability), keberlanjutan lingkungan (environmental sustainability), keberlanjutan sosial (social sustainability).

\section{B. Konsep Hemat Energi Menara Phinisi}

Sebagaimana yang telah dijelaskan sebelumnya mengenai prinsip arsitektur berkelanjutan atau hemat energi maka dapat dilihat beberapa konsep yang diterapkan pada GPPA menara phinisi di antaranya:

1. Pemanfaatan kondisi iklim sekitar.

GPPA menara phinisi merupakan salah satu bangunan yang didesain dengan memanfaatkan kondisi iklim sekitar dengan beberapa rancangan yang diusulkan sesuai dengan fungsi bangunan. Hal ini dapat kita lihat pada data jurnal penelitian yang telah ada yaitu pengaruh distribusi cahaya yang didesain dengan model fasade hyaperbolic paraboloid. 


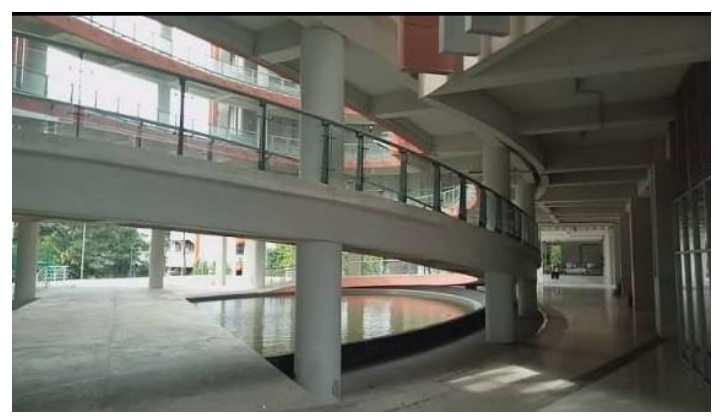

Gambar 4. Pemanfaatan iklim matahari dalam efisiensi penggunaan energi (Sumber: Data pribadi, 2020)

Berdasarkan data penelitian jurnal model pendistribusian cahaya alami pada menara phinisi dengan penggunaan fasade hyperbolic mempengaruhi tingkat iluminasi cahaya yang masuk pada bangunan yang dapat dilihat pada Gambar 5.

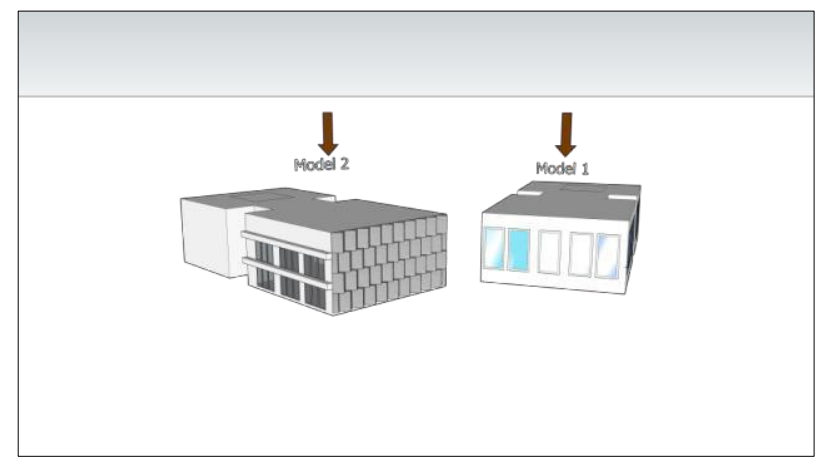

Gambar 5. Model penggunaan fasade digunakan untuk mereduksi kesilauan yang masuk pada bangunan (Sumber: Data pribadi, 2020)

Desain fasade ini disesuaikan pada tingkat kebutuhan cahaya yang digunakan berdasarkan fungsi bangunan. Kelebihannya adalah mengurangi kesilauan yang masuk pada bangunan sebagai konsep kebutuhan cahaya pada fungsi bangunan. Dengan model fasade dan desain yang digunakan, konsep hemat energi menara phinisi lebih ditekankan kepada pemanfaatan udara sebagai kenyamanan termal pada bangunan.
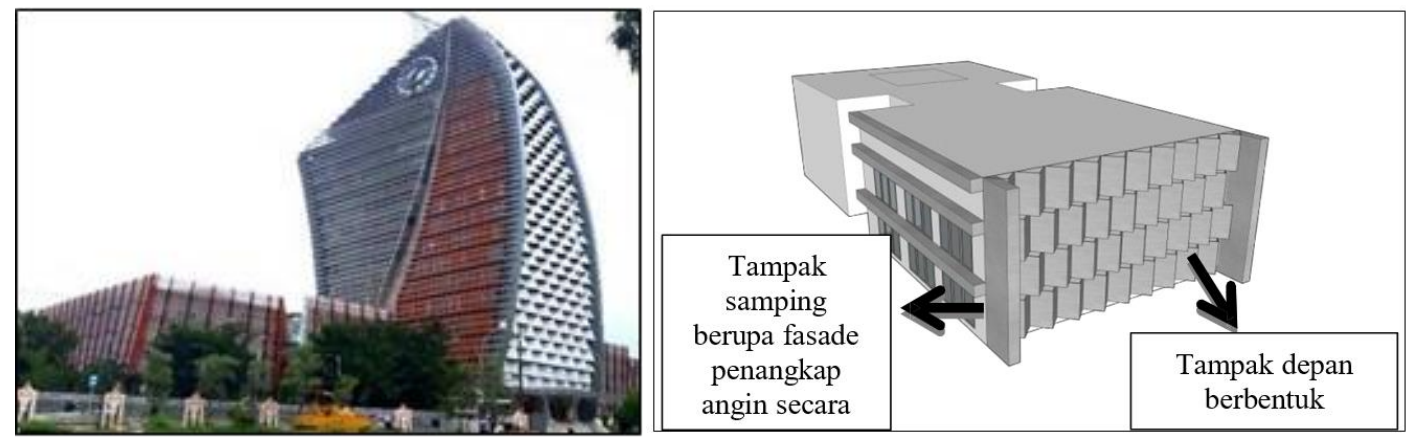

Gambar 6. Model selubung yang digunakan untuk menangkap angin masuk ke dalam bangunan (Sumber: Data pribadi, 2020) 
Selain pada fasade bangunan konsep penghawaan alami dapat kita lihat pada desain bangunan yang menggunakan kolong/panggung dan juga kolam serta void yang terletak ditengah bangunan.
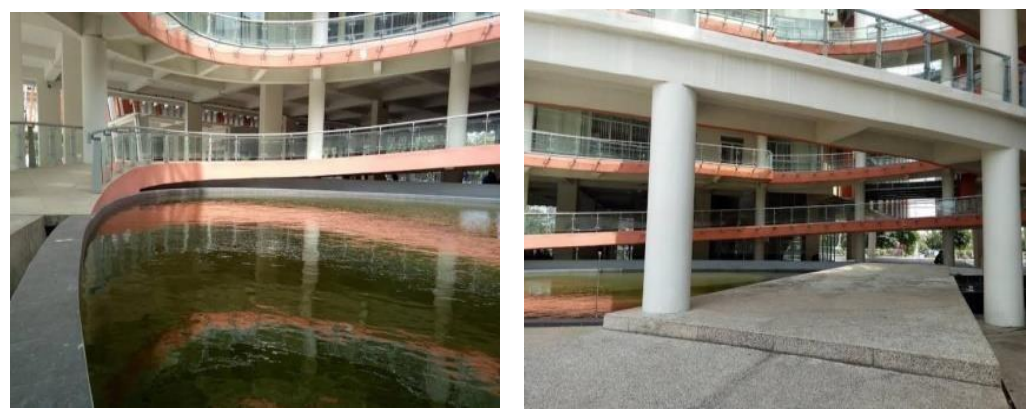

Gambar 7. Void dan kolam (kiri), kolong/panggung (kanan) sebagai pendukung penghawaan alami pada bangunan (Sumber: Data pribadi, 2020)

2. Mempertahankan nilai-nilai dan budaya setempat.

Konsep menara phinisi didesain dengan mempertahankan nilai-nilai dan budaya setempat, yaitu ciri khas budaya orang Sulawesi Selatan dengan layar kapal phinisinya. Selain itu penerapan konsep bangunan adat Sulawesi Selatan yang terdiri atas panggung/kolong rumah yang terbangun. Hal ini dapat kita lihat pada desain bentuk menara phinisi yang menyerupai model kapal phinisi dan juga penggunan panggung/kolong sebagai wujud nilai adat Sulawesi Selatan.

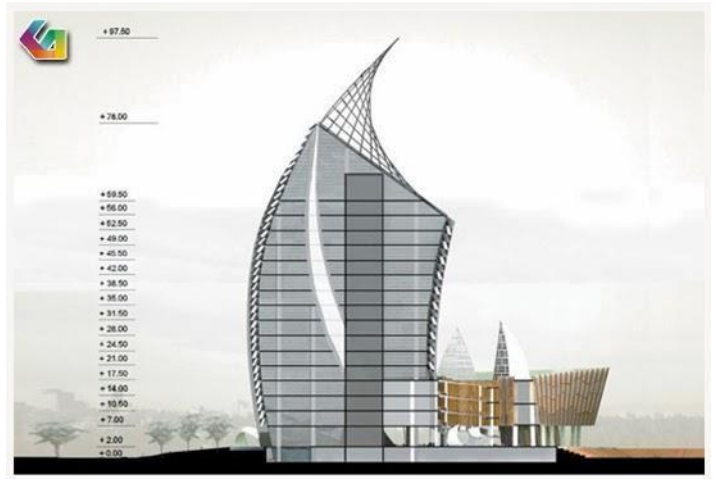

Gambar 8. Model atau bentuk bangunan yang menyerupai kapal phinisi dan juga penggunaan kolong pada bangunan (Sumber: Tim redaksi, 2014)

\section{Elemen-Elemen pada Gedung Menara Phinisi}

Gedung pusat pelayanan akademik menara phinisi merupakan wujud eksplorasi dari model futurisktik yaitu pengembangan dari ilmu pengetahuan dan teknologi dengan model fasadenya yang menggunakan system hyperbolic paraboloid. Dengan model futuristic yang digunakan maka elemen-elemen yang digunakan merupakan perpaduan antara bahan lokal dan juga bahan nonlocal. Berikut merupakan elemen-elemen yang digunakan pada gedung menara phinisi, yaitu antara lain:

1. Kolom beton dan material kaca

Pada Gambar 9 dapat dilihat penggunaan material kolom beton dan kaca digunakan di bagian- bagian tertentu yang disesuaikan dengan pemanfaatan iklim itu sendiri. 


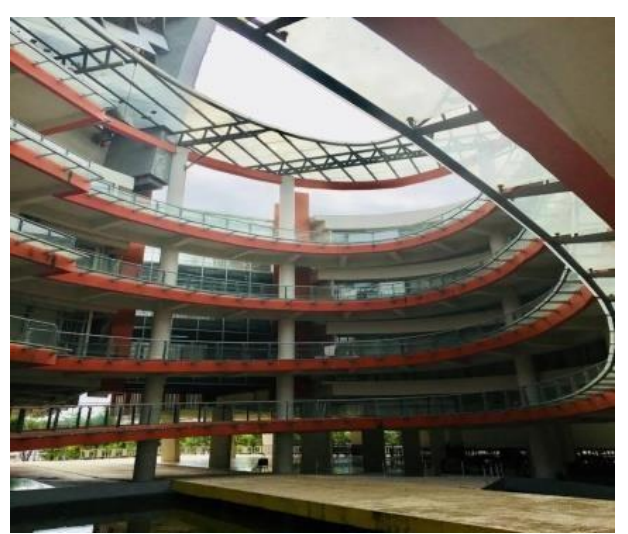

Gambar 9. Penggunaan material kolom beton dan kaca pada bangunan (Sumber: Data pribadi, 2020)

\section{Material penutup bangunan}

Pada penutup tengah bangunan menggunakan pasangan dinding bata yang dilakukan dengan finishing menggunakan material baja dan alumunium sebagaimana ditunjukkan pada Gambar 10.

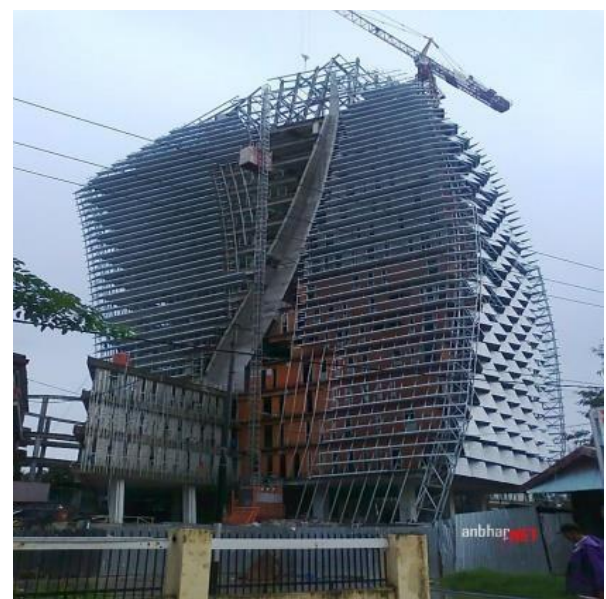

Gambar 10. Penggunaan material alumunium (Sumber: Tim redaksi, 2015)

\section{Lantai Bangunan}

Pada bagian lantai menggunakan keramik, dapat dilihat pada Gambar 11.

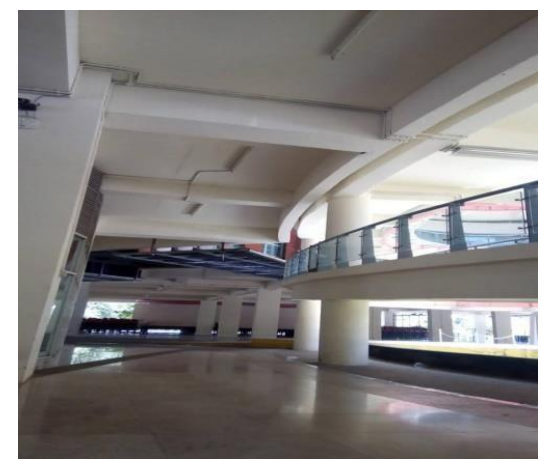

Gambar 11. Penggunaan material kolom beton dan kaca pada bangunan 
4. Struktur rangka atap baja

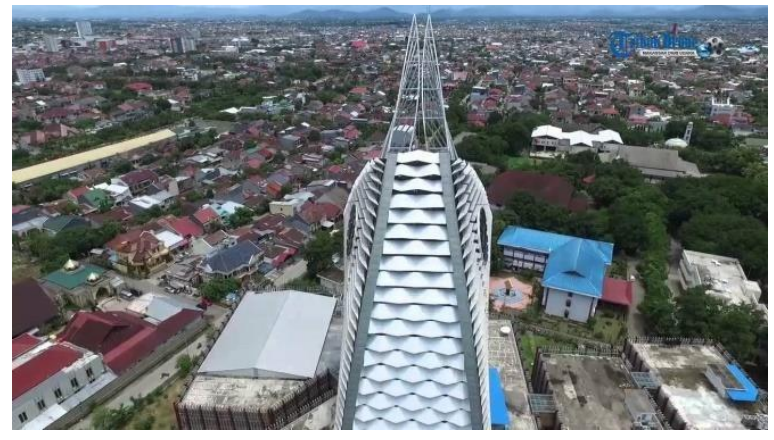

Gambar 11. Penggunaan material kolom beton dan kaca pada bangunan

(Sumber: Tim redaksi, 2015)

\section{KESIMPULAN}

Dari metode analisis yang dilakukan dapat disimpulkan bahwa konsep hemat energi menara phinisi lebih kepada pemanfaatan iklim dimana hal ini cenderung kepada penghawaan alaminya. Adapun kekurangan dari penelitian ini adalah kurangnya rujukan terkait informasi dan data lapangan yang didapatkan dalam menganalisis konsep arsitektur hemat energi dari menara phinisi ini.

\section{DAFTAR PUSTAKA}

Faharuddin, U. (2016). Bentuk Menara Phinisi UNM Makassar terhadap Gerakan Angin dan Aliran Udara pada Lingkungan Sekitarnya dengan Metode. Losari: Jurnal Arsitektur Kota dan Pemukiman.

Jamala, N., R. Rahim \& R. Mulyadi. Tinjauan Tingkat Iluminasi pada Bangunan Gedung Menara Phinisi UNM. seminar.iplbi.or.id.

Latif, S., N. Jamala., \& S. Sam. Pengaruh Desain Fasade Bangunan terhadap Distribusi Pencahayaan Alami pada Gedung Menara Phinisi UNM.

Prakasita, K \& IB. Prayitno. (2012). Green Techno Research Center dengan Pendekatan Arsitektur Hemat Energi pada Pencahayaan dan Penghawaan. Etd.Repository.ugm.ac.id.

Tim Redaksi. 2009. http://rumah-yusing.blogspot.com/2009/01/menara-pinisi.html

Utsman,M.R., W. Suroto, Y Winarto-Senthong. (2019). Penerapan Prinsip Arsitektur Hijau pada Bangunan Kantor Sewa di Surakarta. jurnal.ft.uns.ac.id.

Winarni-Pawon S. (2019). Penerapan Unsur Arsitektur Nusantara pada Karya Desain Arsitek Yu-Sing. Jurnal Arsitektur.ejournal.itn.ac.id.

Zainatun, Z., MR. Rahim., \& A Kusno. (2018). Analisis Reverberation Time terhadap Kenyamanan Audial pada Ruang Auditorium Menara Pinisi UNM. Jurnal Penelitian Enjiniring. 